
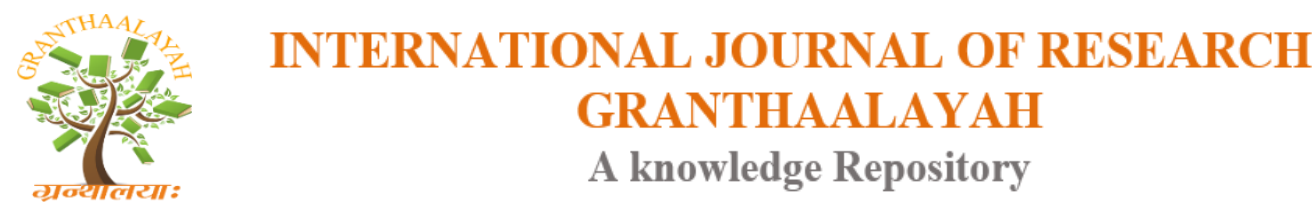

Management

\title{
ASSESSMENT OF MANAGEMENT TRANSFER PROCESS OF WATER SUPPLY SYSTEMS IN SUNSARI DISTRICT OF NEPAL
}

\author{
Anjay Kumar Mishra ${ }^{1}$, Arun Kumar Karna ${ }^{2}$ \\ ${ }^{1}$ Management Consultant at BETON INFRATECH LLP, Pune, India and Visiting Faculty at \\ Shanker Dev Campus, TU. Kathmandu, Nepal \\ ${ }^{2}$ Engineer, Water Supply and Sanitation Division Office, Jhapa, Nepal
}

\begin{abstract}
Considering water is most basic need and highest consumed goods for human being. The overall objective of the study is to identify the root causes of project performance deficiency and analyze the short comings of management transfer process of the system. The functional (Itahari) and partial functional (Duhabi) water supply and sanitation projects of Sunsari district of Nepal were selected for the study.

Expert Consultation and Focus Group Discussion were done for primary source of data whereas reports. Journals, project reports, similar studies, books, websites and audit reports were reviewed for secondary source of data. Comparative performance of both the projects were analyzed based on technical, financial and institutional indicators along with the causes of project performance deficiency

Worsening functionality, Worsening water quality and lost information were the weakness of water supply system lack of standard process, open defecation and financial issues were the main considerations to be taken by users committee to enhance their capacity for well-functioning of the system.

For effective management Transfer of the system minimizing of these short comings, the system should be calibrated and should be sterilized. Project completion document should be handed over to WUSC. WUSC's WOS (Water Operators Standard) document and Business plan should be developed by WUSC in close consultation with the experts and trained WUSC about it. Access to and use of sanitary toilet by all in project area should be promoted. Ensuring these 6 indicators would be a good initiation towards the smooth management transfer.
\end{abstract}

Keywords: Calibration; Sterilization; Business Plan; Financial Sustainability; Operating Process.

Cite This Article: Anjay Kumar Mishra, and Arun Kumar Karna. (2019). "ASSESSMENT OF MANAGEMENT TRANSFER PROCESS OF WATER SUPPLY SYSTEMS IN SUNSARI DISTRICT OF NEPAL." International Journal of Research - Granthaalayah, 7(1), 1-24. https://doi.org/10.29121/granthaalayah.v7.i1.2019.1028. 


\section{Introduction}

The community management approach significantly reduced the burden over the national government's over-stretched resources. This provided the government an opportunity to invest the resources to other important sector. Now it is widely recognized that community participation concept is able to considerably replace some of the loss of the state's implementation capacity. As the policy provided an enabling environment, the number of community managed water supply project significantly increased. More than ever, communities are interested to build their projects by themselves. Nepal WASH sector's community management approach has lots of success to share with rest of the world with a view to empower the community after 2000 the approach of development has focused on participation and now a day the focus of development is shifted to include the excluded i.e. inclusive participation. Based on this accepted approach, in Nepal Decentralize Act 1998 focused on the mode of bottom up development approach to enhance the capacity of community and maximize utility of resources at local level.

National Policy on Rural Drinking Water Supply and Sanitation (2004) provides guidance on water and sanitation service provision in rural areas using community led participatory approaches. According to the data published by the National Management Information Project, the high level of failure of Water Supply System is both surprising and shocking to the policy makers as well as implementers. This result was not anticipated as the widely acclaimed best tool "community management" was used as the key approach. This let to think 'There is something wrong!". The NMIP report recognized that the majority of communities either are not able to manage their systems or not motivated to manage the system.

The maximum water supply projects fail during the operation and maintenance period after management transferred to the WUSC. The study is necessary to identify whether the project performance deficiency is due to lack of WUSC capacity or problem in system's condition. The study will help the DWSS to access the policy environment of water supply project. It will also help to strengthen WSUC's capacity to effective manage the system

\section{Overall Objective}

The overall objective of the study is to identify the root causes of project performance deficiency and analyze the short comings of management transfer process of the system.

\section{Literature Review}

Performance of construction is not satisfactory in terms of time in Nepal (Mishra and Bhandari, 2018). The health facilities at the construction site for causal workers are missing (Mishra and Sharestha, 2017). Mishra and Rai (2017) also compared the different types of building and found performance should improve. Similar, might be the case for water supply which is confirmed by the study conducted by Mishra and Acharya (2018) for Salyankot Water Supply Project of Dhading District shows that the present physical structures are in satisfactory condition having index of $56.81 \%$ and before earthquake was found good having index 95\%, was in good condition taking 10 indicators. Due to no flow of water from three sources after source get depressed and decrease in water for remaining three water source after earthquake, demand is more than supply. The quality of water has found within the prescribed range of National Drinking Water quality System based on physical, chemical and microbiological parameters. From the study it is 
concluded that the accessibility of the people to the stand post in average is good. The average distance for the beneficiaries HHs and the stand post is less than $100 \mathrm{~m}$. The system focuses on equality rather than equity without considering the family size. Operation and maintenance of the project lacks in terms of conducting timely general assembly, users meeting, record keeping, tariff collection, gender equity and social inclusion. It depends on VDC offices, District Development Office (DDC) and WSSDO Dhading for operation and maintenance due to lack of its own sufficient fund as O\& M fund shortage of 27,280 for fiscal year 072-73. According to Mishra (2018), Salyankot Water Supply Project is presently functioning with current Functionality index of 58.4\%. For the condition before earthquake it is found that this project was running properly with the functionality index of $71 \%$. According to Mishra (2018), T the conventional practices used in the design process of a project are best and no other techniques should be followed in the design process is assumption of professional rather than using Value Management. Though according to a survey conducted by Mishra (2018) on Existing Class A Construction Companies ware much more capable in terms of HR (Numbers, Experience \& Projects Handled)

\section{Standard Process}

Standard operating procedures (SOPs) are written instructions intended to document how to perform a routine activity. Many companies rely on standard operating procedures to help ensure consistency and quality in their products. Standard operating procedures are also useful tools to communicate important corporate policies, government regulations, and best practices.

A standard Operating Procedure (SOP) is a document that contains accurate and detailed instructions to perform a process or procedure to ensure that the procedure is performed the same way each time and the same way by each person.(GLEASON, 2013)

Procedures provide a description of who does what, when. An SOP characterizes relationships and control measures. It defines the roles and responsibilities to help workers "find themselves"• in the business process. Procedures clarify different decision points and provide the necessary guidance on criteria to make a decision.(Anderson, 2013)

\section{Process Procedures Journey Flowchart}

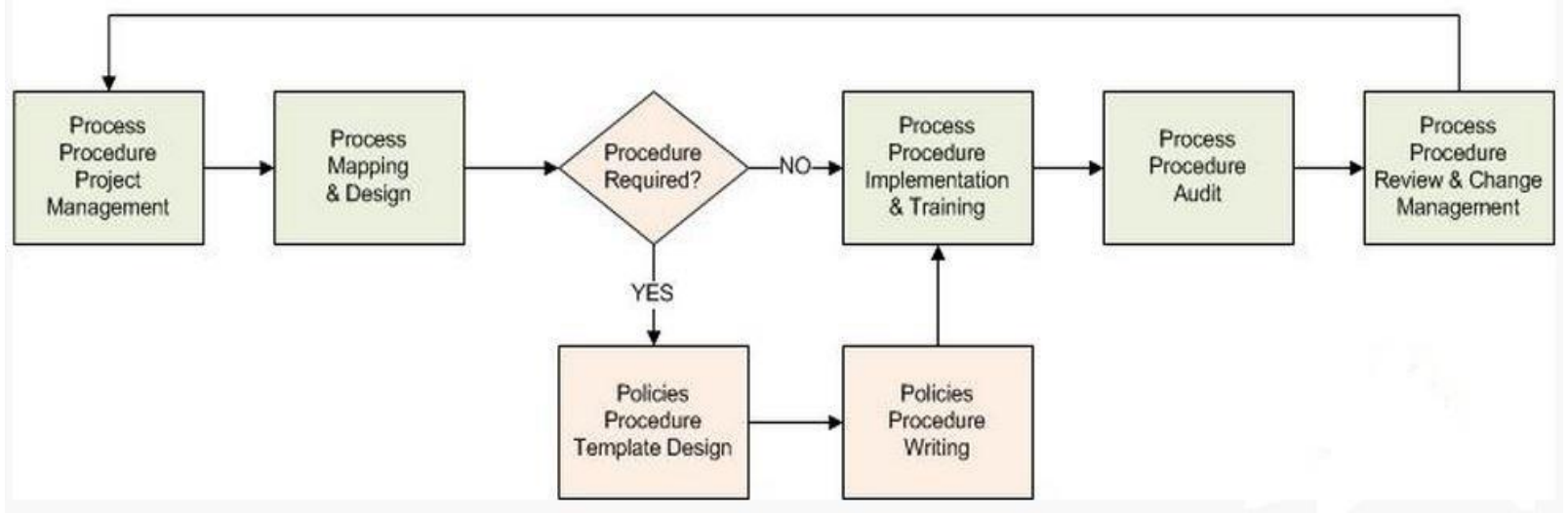

Figure 2.1 Process Procedures Journey Flowchart 
In Nepal, the WUSC members are elected from the community. They do not require any special qualification and prior experience of water supply system. Neither DWSS has recommended any qualification and experience for office staff of WUSCs. The system is community managed, so they do not have enough financial strength or attitude to employ qualified technicians. This always result the employing the less competent person for service. Moreover, WUSC always prefers to employ the person within from their community. Though the WUSC has extreme motivation to run the system, they virtually have to run the system with these inexperienced circumstances.

\section{Financial Sustainability}

Rural water supply scheme sustainability is whether or not facilities provide the designed level of service (water quantity and quality) continues over the designed time period (Abrams, 2013). Sustainability of water supply schemes is whether benefits from the service continue satisfactorily until the end of the design life. Benefits include health benefits through providing improved quality of water from protected source, water delivery to reduce time spent and convenience (Mebrahtu, 2012).

Sustainable rural water supply is defined as one in which the water sources are not over-exploited but naturally replenished, facilities are maintained in a functional state which also ensures a reliable and adequate water supply and also benefits of the supply continue to be realized by all users over a prolonged period of time. Enabling rural water supply scheme to remain operational over the design period requires a number of complex and interrelated technical, social, environmental, financial and managerial issues upon which failure in meeting any of these can lead to failure of scheme (Abrams, 2013). The same source pointed out that "if the water flows, then all of the many elements which are required for sustainability must have been in place. There must have been money for recurring expenses and for the occasional repair, there must have been acceptance from the consumers of the service, the source supplying the service must have been adequate, the design must have been properly done, and there must have been sound construction."

Sustainability pertains to multiple aspects of a rural water supply, with institutional, social, technical, environmental and financial dimensions (WELL, 1998). This accounts for the fact that understanding and measuring sustainability is so difficult, and why solutions are highly context specific. Conceptual frameworks, such as the one below, have been developed to capture the interlinkages that relate to sustainability, a weakness in anyone of which can lead to failure of the scheme.

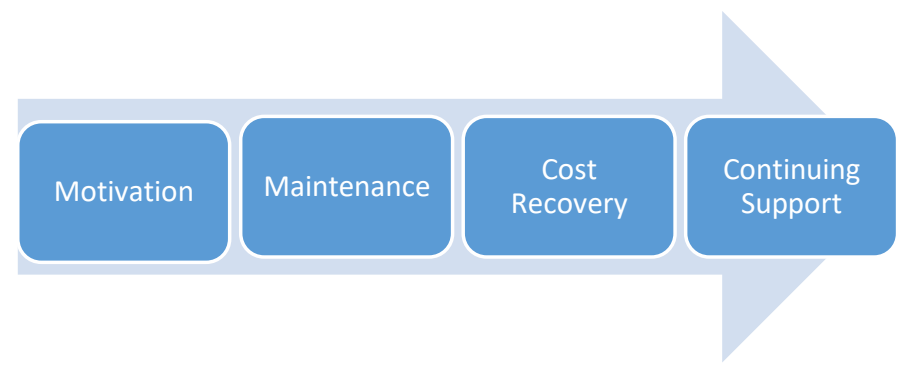

Figure 2.2: The Sustainability Chain, Carter et al 1999

Sustainability is about the inter-relationship of natural resources, physical assets and the services they provide; the people and organizations which use and manage them; and the rules and financial 
systems which facilitate effective management.(Carter et al, 2010 cited in MebitMitiku Bitew,2013).Factors such as capacity and willingness to pay, as well as cost sharing and community financial management, are likely to influence the financial sustainability of the systems. Finance becomes more and more relevant, especially in a context where communities are being empowered with new financial responsibilities. (Nyumbu, 1990)

In Nepalese perspective, the WUSC members are elected from the community. During the election they generally promise not to increase water tariff. After the management transfer the government does not provide any financial support from public expenditure. This poses serious threat to the financial health of the system. Being small community system WUSC do not have any other financial source than tariff. They also do not have skill of fund generation.

\section{Open Defecation}

Open defecation refers to the practice whereby people go out in fields, bushes, forests, open bodies of water, or other open spaces rather than using the toilet to defecate. The practice is rampant in India and the country is home to the world's largest population of people who defecate in the open and excrete close to 65,000 tonnes of faeces into the environment each day. Around 595 million people, which is nearly half the population of India, defecate in the open. India accounts for 90 per cent of the people in South Asia and 59 per cent of the 1.1 billion people in the world who practise open defecation(UNICEF, 2012).

Open Defecation means defecting in the open and leaving the faeces exposed. ODF means no faeces are openly exposed to the air. The collection of faeces in a direct pit with no lid is also a form of OD but with a fly proof lid it then qualifies for ODF. The following indicators are expected to be prevalent in any given designated area in order to declare it ODF:-

- There is no OD in the designated area at any given time;

- All household have access to improved sanitation facilities with full use operation and maintenance; and

- All the schools, institutions and offices within the designated areas must have toilet facilities(NMIP, 2014).

In Nepal, open Defecation is one of the major problems, which has direct consequence to health and dignity. Use of hygienic toilet is best practice, yet lacking in many parts of Nepal. The recent report published by NMIP/DWSS shows that only $70.28 \%$ of the Nepalese population are using toilet facility. The project should promote the construction of toilet and behavior change.

\section{Information Management}

According to (Malik, 2010) management is the transformation of resource to utility. Wikipedia defines management as organization and coordination of the activities of an enterprise in accordance with certain policies and in achievement of clearly defined objectives.

During the hasty situation of management transfer, the WUSC are not that much bothered of project documents. This information gradually fades out from the memory of WUSC members. But after several years when there are lots of changes in project features and there are new WUSC members this information is lost somewhere. Sometime the WUSC members who lose his election do not want to share this information. For example after sometime they will even be unable to find the exact route of pipe laying, location of valves etc. 


\section{Project Handover System}

Project handover is a process of transferring a project from one team to another team which is supposed to keep working on this project in the context of certain duties, for example it could be a handover of software product from the developers to the customers.

There are different forms of handover - for example: forced handover when the previous team fails to accomplish the work (due to some technical, financial or political reasons), and the project is transferred in an incomplete state, so that the next team possessing necessary resources can proceed working at it and will finally finish it; and expected handover, like handing over the project's products from producers to customers.

Stage between Completion stage and Operational stage:

The process model shows the project is divided into a number of stages (see Figure 2.3) that are followed in sequence from start to finish of the project. This model consists of six steps: preproject work, start-up or initiation stage, development stage, completion stage, operational stage, and last post-project review stage. Handover process takes place between the completion stage and the operational stage (Cadle\&Yeates, 2008, 92 cited in (Laine, 2012).

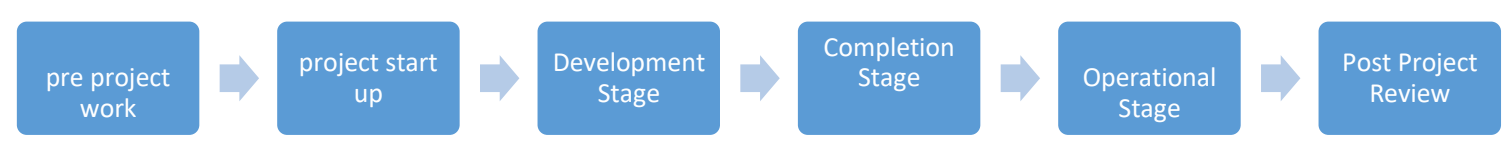

Figure 2.3 Stages of a software development project (Cadle\&Yeates, 2008, 93,cited in Markus Laine,2012).

When the project result has been completed by the supplier and has been subjected to the full rigors of a system test and every error and problem eradicated, the Completion stage begins. This stage means that the associated technical documentation, user manuals, operating instructions and any other documentation should be finished at this point. This stage is where the customer receives the finished product and carries out a number of examinations and tests in order to confirm that the system meets the specification which was agreed between end-user and supplier. The acceptance of the completed system by the end-user culminates this stage. The steps of this stage are delivery to the end-user of all the elements of the system, like software and documentation; training endusers, system administrators and operators; carrying out of acceptance tests by the end-user; acceptance by subscriber; and system commissioning, which means go-live procedures. Delivery to the end-user should be handled by a formal handover with all the deliverables being held under configuration management. The final end-user takeover means the point where subscriber formally accepts the system and the project comes to an end. (Cadle \&Yeates, 2008, 113-115 cited in Markus Laine, 2012).

In Nepalese perspective, Rural Water Supply Projects has been generally physically completed in at least 7-8 years. After physically completion of the project, WSSDO organize training called post construction training for three days. After this training, project is handovered to the WUSC with handover certificate and some equipment for operation and maintenance. 
The recent status survey reports of nearly 38,000 community managed projects in Nepal, published by the National Management Information Project (NMIP) of the Department of Water Supply and Sewerage (DWSS), show that only $25.4 \%$ of the projects are fully functional, others have some degree of poor functionality.

\section{Concept of Capacity Development}

The United Nations Development Programme (UNDP) defines capacity development as the process through which individuals, organizations, and societies obtain, strengthen, andmaintain the capabilities to set and achieve their own development objectives over time (UNDP, 2008). For the Deutsche GesellschaftfürInternationaleZusammenarbeit (GIZ) GmbH capacity development is the process of strengthening the abilities of individuals, organizations and societies to make effective use of the resources, in order to achieve their own goals on a sustainable basis (GTZ, 2003).

In a general manner, capacity is understood as the ability of people, organizations and society as a whole to manage their affairs successfully. Capacity development thus is a change process "whereby people, organizations and society as a whole unleash, strengthen, create, adapt and maintain capacity over time" (OECD, 2006).

Austrian Development Agency (ADA, 2011)states that the capacity development in the broadest sense is about strengthening the abilities needed for successfully performing tasks, achieving results, identifying problems, finding solutions and taking sound decisions in the respective professional and living environments. Individuals and organizations are always embedded in a certain social and institutional context and interact within this framework through formal and informal mechanisms. Adequate measures for capacity development must therefore always take into account all three levels - the individual, the organizational and the enabling environment and systematically analyze the interactions amongst them.

In the water supply domain, capacity means a system has the technical, managerial, and financial capabilities to consistently deliver safe and adequate water. Capacity development refers to an increase in a system's ability to provide safe and reliable drinking water to its consumers. Capacity development is an on-going process of trying to find more efficient ways of running and operating a system while planning for the long-term (USEPA, 2001).

Environmental Protection Agency of United States (USEPA, 2001)states that the capacity development in water supply has three interrelated components in providing safe drinking water sustainably to the users: technical, financial and managerial.

- Technical capacity includes the physical and operational ability of a system to meet the requirements of drinking water standards. It refers to the physical components of the water supply system, including the characteristics of the source water, the adequacy of treatment, and the condition of the pump, treatment, storage, and distribution systems. Technical capacity also refers to the technical knowledge and capability of system personnel to properly operate and maintain the system.

- The financial capacity means the system has the ability to acquire and manage sufficient financial resources to achieve and maintain the requirements of the system. The financial requirements of the system include capital cost and operational cost. The capital cost is 
required for facility expansion and rehabilitation, and operational cost for salaries and wages, power, chemicals, spare parts, repair and maintenance, office management, etc. A system with adequate financial capacity will have the revenue sufficiency to cover all costs and will invest in infrastructure replacement.

- The managerial capacity refers to the overall organizational structure of the system. A system with adequate managerial capacity has a clearly identified owner who is accountable for the system. The staffing and organization of the system allows the efficient use of human resources and assigns clear authorities and responsibilities between the Committee or Chairman, managers, operators and consumers. Further, the system enjoys effective linkages to people and organizations that can provide help in case of need.

Financial capability represents a critical shift of moving beyond financial education to adopting new behaviors that individuals can use to identify and utilize appropriate financial tools and make sound financial decisions in order to build and preserve their assets over time. Financial capability allows transform of financial knowledge into effective action (Citi, Website).

Similarly, organizational capability is the ability of a utility to manage people and to gain competitive advantage. It focuses on internal processes and systems for meeting consumer needs and ensures that employee skills and efforts are directed toward achieving organizational goals and strategies. Organizational capability reflects on utility's responsiveness on meeting the need of consumers, on relationship between consumer and employee and on the quality of services it provides to the consumers. Organizational capabilities are anything a company does well that improves business and differentiates the business in the market (Kelchner, Webpage).

\section{International Practice}

Tackling the specific global challenges faced by the water sector requires not only increased investment, but also appropriate water management. In addition, there needs to be a social dialogue to implement quality and supply standards as well as the long-term funding of this vital service (GTZ, 2012). To tackle the challenges, in most of the countries, responsibility for water supply has been transferred by the central government to the local governments, private operators or user associations (WB, 2010). Capacity development of the water supply providers is therefore has been a priority in all countries to improve the quality of water services.

At organizational level, German capacity development providers aim to establish efficient water utility service providers that are operated on a commercial basis and also in a socially and environmentally responsible manner. Ideally these providers finance themselves via cost-covering tariffs, and also expand access to water and sanitation services for poor sections of the population. They support the introduction of governance tools such as business development plans and tariff regulation plans, as well as the development of strategies to improve the implementation of technical and legislative guidelines (GTZ, 2012).

The World Bank in Nairobi organized a workshop on Sustainable Management of Small Piped Water Systems in Africa held in Maputo, Mozambique from October 6-8, 2010 (WB, 2010). The workshop aimed to take stock of twenty years of efforts in African countries to improve the quality of water supply services by delegating the management of small water schemes to private operators 
or user associations. In most of the African countries, the population served by a small water scheme ranges from 2,000 to 50,000 depending on national definitions.

The workshop documented a strong growth of delegated management over the last ten years. In most countries, operators are contracted based on competitive tenders. The more dynamic operators have been able to expand the numbers of schemes they manage to as many as 28 (Benin) and 40 (Niger). Other contractual and institutional arrangements also exist: in some countries the central government remains the asset holding authority (Mauritania, Senegal), in others, community based organizations function as operators (Senegal, Uganda, Kenya), and in yet others, municipal management is still common (Ethiopia, Mozambique, Tanzania) (WB, 2010).

Workshop participants identified six areas of intervention to move towards sustainable management of small piped water schemes in rural areas and small towns. These interventions were organized into three main action areas: (i) establishment of an enabling environment, (ii) capacity building, and (iii) hands-on support in the field. Capacity building is a priority in all countries. It can be organized around training modules targeting each of the key stakeholders including local governments, operators, regulators and water departments (WB, 2010).

United States Environmental Protection Agency of the United States of America has introduced National Capacity Development Strategic Plan to focus available resources toward assisting public drinking water systems in acquiring and maintaining the technical, managerial, and financial capacity to meet the public health protection standards aimed at ensuring safe drinking water (USEPA, 2008). Similarly, USEPA has provided Handbook for Capacity Development: Developing Water System Capacity under the Safe Drinking Water Act as Amended in 1996 with a comprehensive discussion of the history and objectives of capacity development and the programs in place to support the initiative(USEPA, 1999).

USEPA has designed Capacity Development Strategic Plan and Handbook to help small system (serving fewer than 3,300 people) owners and operators, state and tribal agencies, technical assistance providers, and consumers to provide safe drinking water and protect public health. Every state of the United States of America has to comply with the USEPA rules, regulations and guidelines and are obliged to provide assistance to small water systems for implementing capacity development program to improve or optimize their finances, management, infrastructure, and operations so they can provide safe drinking water in a consistent and cost-effective manner.

\section{National Practice}

In Nepal, government and non-governmental agencies involved in the sector implement or facilitate WUSCs to construct water supply systems and transfer O\&M responsibilities to WUSCs after completion of the construction. It has been observed that none of the organizations have practiced yet to assess the capacity of local WUSCs before transferring O\&M management to them. Instead of enhancing WUSC's capacity adequately, organizations' activities are limited merely to the arrangement of an O\&M fund during construction period. As a result, WUSCs have no clear understanding of the concept of O\&M.

RWSSFDB, in its project information sheet (RWSS, Website)states that it provides technical, institutional and financial support to Support Organizations (SOs) and communities to implement 
rural water supply and sanitation schemes and other related activities. It advocates that it takes an integrated approach to delivering inclusive and sustainable water supply and sanitation services including associated software activities. Apart from water supply and sanitation, other programme components include institutional development, capacity building and skill development, women empowerment, social capital formation and mobilization, social accountability and economic development that make distinct from other actors working in WASH sector of Nepal.

The implementation phase activities include: training to SOs' staff and community members, procurement of non-local construction materials and construction of water supply schemes. The outcome of the implementation phase is the consolidation of all development and implementation phase activities, a completed and functioning water supply and sanitation scheme, and trained WUSC, VMW and community members to operate and maintain the scheme (RWSS, Website).

Nepal Water for Health (NEWAH) is a national level NGO in Nepal working towards clean drinking water, hygiene promotion and sanitation. It advocates that capacity building is an increasingly important pillar for effective local level planning, implementing, monitoring, evaluation and operation of WASH systems. The capacity of local people, Village WASH Coordination Committees, District WASH Coordination Committees, and other support agencies needs to be enhanced in order to contribute to the functionality of systems. NEWAH also advocates that its Capacity Building and Advisory Service division has been expanding its services for sector capacity building in such areas (NEWAH, Website). However, concrete evidence of its capacity building activities could not be revealed from its documents.

The rural and urban water supply and sanitation policies of Nepal (MoPPW, 2004) have clearly stated the need for capacity development of water supply for safe and sustainable services to the people. However, the capacity development of WUSCs even in the programme of DWSS has limited only to the training to WUSCs during implementation of the schemes, which usually does not cover the specific needs of O\&M. The WUSCs are managing O\&M of water supply schemes on their own limited knowledge, skill and capacity and providing water supply services to the people.

\section{Project for Capacity Development on Water Supply in Semi-Urban Areas}

Realizing the gap between WUSCs' capacity and management need in O\&M of water supply facilities and services, JICA implemented a Project for Capacity Development in Water Supply in Semi-Urban Areas in Nepal, nicknamed as WASMIP (Water Supply Management Improvement Project) afterwards, in some of the water supply projects in Jhapa and Morang districts from January 2010 to September 2013. During this period, a team of Japanese experts in collaboration with DWSS personnel conducted series of on the-job training (OJT) and workshops to enhance technical, financial and managerial capacity of WUSCs. Training of Trainers (To T) was also conducted to the staff of DWSS and Water Supply and Sanitation Division Offices (WSSDOs) of Jhapa and Morang (JICA, 2013).

Implementation of the project was followed by capacity assessment of WSSDOs and WUSCs, development of Standard Operating Procedures (SOPs) for the operation and maintenance of the facilities and equipment provided in the systems, class room lectures, OJTs and workshops based 
on SOPs, and development of small- and medium-sized water supply management and support models known as WASMIP Models.

Based on the institutional and personnel assessment, SOPs were prepared for O\&M of water treatment plant and water quality management, O\&M of water distribution facilities, and water meter reading and meter calibration control to strengthen technical aspect. The Expert's team together with WUSCs developed Business Plan to address financial and managerial issues. SOPs and Business Plan were applied in WUSCs to realize the applicability in the field through OJTs and workshops. Similarly, supervision and monitoring capacity of WSSDOs was strengthened by To Ts simultaneously.

As an output of the capacity development project, Expert's team developed a Water Supply Management Model for the improvement of technical, financial and management capacity of WUSCs, and a Water Supply Support Model to provide guideline to DWSS and WSSDOs on extending support to WUSCs. These models are submitted to DWSS to implement them for capacity development in other similar semi-urban water supply projects throughout the country.

\section{Performance Evaluation Indicators}

The capacity development program should build a body of evidence allowing independent judgment of how much success the program achieved in accomplishing the learning outcomes. At completion, the program team assesses the achievement of learning outcomes, status of the capacity indicators, and progress toward the development goal (WB, 2009a). Indicators to assess the changes caused by capacity development program should have been identified while designing the program and defining the outcomes.

Appropriate indicators for assessing capacity development outcomes could be quantitative or qualitative, depending on the nature of the capacity change desired. The process of selecting indicators should always include the consideration of existing data sources and/or the feasibility of collecting the relevant data. Changes in stakeholder perspectives or behaviors are often tracked via surveys whereas changes in the operational efficiency of an organization might be captured through the analysis of existing administrative records. If existing indicators are not sufficient, it is possible to conduct additional data collection and/or analysis after project completion (WB, 2012).

The World Bank through its International Benchmarking Network for Water and Sanitation Utilities (IBNET) has been involved in water sector monitoring collecting data on utilities' performance and has set a global standard for performance assessment of water utilities based on a variety of indicators. IBNET blue book creates a baseline and, at the same time, offers a global vision of the state of the sector in developing countries (Danilenko, 2014).

IBNET indicators include median and un-weighted average values of the performance indicators based on the data and information from more than 4,400 utilities from 135 countries. The median values are regarded as a better representation of performance than the average because of its skewness. Specified values of indicators are widely used on assessing and comparing performance of water supply utilities worldwide (Danilenko, 2014). Similarly, World Bank has assessed 
performance of water supply utilities in Africa using some of the key financial and organizational capacity indicators (WB, 2009b).

Some of the capacity indicators defined by IBNET (Danilenko, 2014) and indicators used for performance assessment of water supply utilities in Africa (WB, 2009b) and their values relevant to the study are as follows:

1) Water Supply Coverage: Median water supply coverage for households in low-income countries 62 percent, compared to 81 percent in lower middle-income countries, 93 percent in upper middle-income countries, and virtually 100 percent in high-income countries.

2) Water Consumption: Water consumption shows diverse patterns between income groups and between regions, depending on economic growth trends and differences in real tariff developments. Median water consumption in 2010 is 158 liters per capita per day.

3) Nonrevenue Water: Non-revenue water (NRW) represents water that has been produced and is 'lost' before it reaches the consumer either through leaks, theft or through legal usage for which no payment is made. NRW captures not only physical loss but also losses due to inefficient billing or illegal connection (referred to as commercial losses). Water loss levels vary widely per country and within one country per city. A certain level of water losses cannot be avoided from a technical point of view and /or is considered acceptable from an economic point of view. However, high levels of NRW indicate poor system management and poor commercial practices, as well as inadequate pipeline maintenance, low technical capacity and capability of personnel (WB, 2009b).

NRW can be calculated as a percentage, as volume lost per unit length of network per day $\left(\mathrm{m}_{3} / \mathrm{km} /\right.$ day) or as volume lost per connection per day ( $\mathrm{m}_{3} / \mathrm{conn} /$ day). But, most commonly, NRW is calculated as the difference between water produced and water sold, and measured as a percentage of water produced. Median NRW in 2011-27 percent. When measured by water volume lost as a percentage of water production, NRW is highest in low-income countries and lowest in high-income countries.

4) Staff Productivity: Measured as the number of staff per 1,000 connections, where higher productivity is reflected fewer staff per 1,000 connections. Staff productivity varies widely from about 11 employees per 1,000 connections in low-income countries to slightly more than 3 in upper middle income countries.

5) Personnel or Labor Costs: Median labor costs as a percentage of total operating costs, about 36 percent in low-income countries in 2010, compared to about 40 percent in middleincome countries.

6) Operating Cost Coverage Ratio (OCCR): defined as the ratio of total annual billed revenues to total annual operating costs (excluding interest and depreciation). Utilities inlow-income countries have a median OCCR of 1.09, compared to 0.99 in lower middle income countries, 1.12 in upper middle-income countries, and 1.42 in high-income countries.

7) Average tariff per m3sold - expressed as the ratio of a utility's total annual direct billed revenue to total annual water consumption (volume of water sold). Direct revenue is the actual amount billed for water services. Domestic, commercial and industrial revenue is included but bulk water revenue is excluded. Revenue from other sales, sundry income or interest received is excluded as are direct revenue subsidies. 
8) Unit operating cost per m3sold - expressed as the ratio of a utility's total annual operating expenses and total annual volume of water sold.

9) Collection ratio - defined as the ratio of a utility's actual revenues collected and total billed revenues, expressed as a percentage.

\section{Methodology}

First of all, problems were identified and then generated the research questions and objectives. Primary and secondary data were collected by different sources.

\subsection{Study Area}

Sunsari district was taken for study area because Sunsari district has mixed community and it is near to the Indian boarder also. There are 31 rural water supply projects managed by WUSC in Sunsari district. As NMIP data shows that there are $25.4 \%$ of water supply projects are functioning well, the rural water supply project of Sunsari district also face such functioning problem. Among them only two projects were taken as sample. One of them was Itahari water supply project which was functioning well and another was Duhabi water supply project which was less functioning with a view to assess what was differences in their functionality status.

\subsection{Silent Feature}

Table 3.1: Silent Features of the systems

\begin{tabular}{|l|l|}
\hline \multicolumn{1}{|c|}{$\begin{array}{c}\text { Name of Project: Itahari Water Supply } \\
\text { Project }\end{array}$} & $\begin{array}{c}\text { Name of Project: Duhabi Water Supply } \\
\text { Project }\end{array}$ \\
\hline Date of Handover of Project: $2053 / 03 / 27$ & Date of Handover of Project: 2053/02/13 \\
\hline Benefitted Household: 11756 & Benefitted Household: 3145 \\
\hline
\end{tabular}

Itahari Water Supply Project was hand overed to the WUSC in 2053/03/27. Only $2394 \mathrm{HH}$ were benefited by this system. Itahari VDC was declared as Municipality in 2054. Due to high population growth and urbanization, the system unable to fulfill the demand and the system again extended and modified on the grant of ADB. The system was able to fulfill the demand up to 11756 $\mathrm{HH}$. There are 284 elected members in WUA and 9 WUSC's members. There are 43 permanent and 10 daily wages staffs are working in the system.

Duhabi Water Supply Project was hand overed to the WUSC in 2053/02/13. Only 3145 HH were benefited by this system. Due to high population growth and urbanization, the system unable to fulfill the demand and the system was started for extention and modification on the grant of ADB in 2067/01/27. The system modification was postponed due to unavoidable political situation. The extension of the system was again started in 2070 BS and will be completed in F.Y 2073/074. HH. There are 11 WUSC's members, 6 permanent and 3 daily wages staffs are working in the system. 


\subsection{Technical Feature}

Table 3.2: Technical Features of Itahari Project (WUSC,2016)

\begin{tabular}{|l|l|l|l|l|l|}
\hline S.N. & Description & Nos./ Capacity & S.N. & Description & Nos./ Capacity \\
\hline 1 & Overhead Tank & $3 / 450$ cum & 2 & Deep Tubewell & $6 / 20$ LPS \\
\hline 3 & Filtration Tank & 3 & 4 & Generater 100 KVA & 3 \\
\hline 5 & Valve Chamber & 72 & 6 & Guard House & 3 \\
\hline 7 & Water Quality Lab & 3 & 8 & Pump House & 3 \\
\hline 9 & Transformer 100KVA & 3 & 10 & Pannel Board & 6 \\
\hline 11 & Transmission Pipeline & $400 \mathrm{~m}$ & 12 & Distribution Pipeline & $225 \mathrm{~km}$ \\
\hline 13 & Buster Pump & 6 & 14 & Fire Hydrant & 22 \\
\hline 15 & Office Building & 1 & & & \\
\hline
\end{tabular}

The above table shows the technical feature of Itahari Water Supply Project. There are three numbers of 450 cum capacity reservoir tanks which balanced the demand of Itahari Water Supply Project.

Table 3.3: Technical Features of Duhabi Project (WUSC,2016)

\begin{tabular}{|l|l|l|l|l|l|}
\hline S.N. & Description & Nos./ Capacity & S.N. & Description & Nos./ Capacity \\
\hline 1 & Overhead Tank & $1 / 450$ cum & 2 & Deep Tubewell & $3 / 20$ LPS \\
\hline 3 & Filtration Tank & 0 & 4 & Generater 100 KVA & 1 \\
\hline 5 & Valve Chamber & 39 & 6 & Guard House & 1 \\
\hline 7 & Water Quality Lab & 0 & 8 & Pump House & 2 \\
\hline 9 & Transformer 100KVA & 1 & 10 & Pannel Board & 3 \\
\hline 11 & Transmission Pipeline & $680 \mathrm{~m}$ & 12 & Distribution Pipeline & $31.24 \mathrm{~km}$ \\
\hline 13 & Buster Pump & 6 & 14 & Fire Hydrant & 22 \\
\hline 15 & Office Building & 1 & & & \\
\hline
\end{tabular}

The above table shows the technical feature of Duhabi Water Supply Project. There are only one 450 cum capacity reservoir tanks which balanced the demand of Duhabi Water Supply Project.

\subsection{Sampling and Population}

The system has been covering more than 11 thousands and 3 thousands households. So, Sampling for these large households could not be surveyed. That's why information was generated through FGD.

\subsection{Data Collection}

\section{Primary Data}

Expert Consultation and Focus Group Discussion are the sources of primary data.

\section{Expert Consultation}

Experts were selected by judgmental sampling. SDE of WSSDO Sunsari, WASH Engineer of ITECO and Engineer of WSSDO, Sunsari were taken as expert team. Expert Consultation was conducted for generalize ideas. 


\section{Agendas of Expert Consultation}

- About Technical Problems of WSSP

- About Software parts of WUSC

- About Administrative system of WUSC

- About Financial system of WUSC

- About O \& M system of WSSP

\section{Focus Group Discussion}

Since the system has been covered more than 11 thousand household, seven FGD in Itahari Water Supply Project and six FGD in Duhabi Water Supply Project were conducted and collected the information for fulfillment of the objective.

Table 3.3: FGD in Itahari Water Supply Project

\begin{tabular}{|l|l|l|}
\hline Community & Number of members & Date \\
\hline WUSC members & 5 & $2073 / 01 / 08$ \\
\hline Panchrukhi & 7 & $2073 / 01 / 08$ \\
\hline Jutbikashchauk & 6 & $2073 / 01 / 08$ \\
\hline B.P.Chauk & 7 & $2073 / 01 / 09$ \\
\hline Biratnagar line & 5 & $2073 / 01 / 09$ \\
\hline Aapgachhi & 6 & $2073 / 01 / 10$ \\
\hline WUSC maintenance staffs & 4 & $2073 / 01 / 10$ \\
\hline
\end{tabular}

In Itahari Water Supply Project, first of all, the service area was divided in five clusters. One FGD from each cluster was conducted for gathering information. One FGD from WUSC members and another one FGD from WUSC maintenance Staffs were conducted.

Table 3.4: FGD in Duhabi Water Supply Project

\begin{tabular}{|l|l|l|}
\hline Community & Number of members & Date \\
\hline WUSC members & 5 & $2073 / 01 / 24$ \\
\hline Bus Stand & 6 & $2073 / 01 / 24$ \\
\hline RastriyaBanijya Bank & 6 & $2073 / 01 / 25$ \\
\hline SukumbasiTole & 5 & $2073 / 01 / 25$ \\
\hline Buddha chauk & 7 & $2073 / 01 / 26$ \\
\hline WUSC staffs & 4 & $2073 / 01 / 26$ \\
\hline
\end{tabular}

In Duhabi Water Supply Project, first of all, the service area was divided in four clusters. One FGD from each cluster was conducted for gathering information. One FGD from WUSC members and another one FGD from WUSC Staffs were conducted.

\section{Agendas of FGD}

- Technical Issues

- Quality Issues

- Administrative Issues

- Financial Issues

- ODF 
- Information System

\section{Quality Test}

Four water samples (source, RVT, Tap1 and Tap2) in each project were tested in Eastern Region Water Quality Testing Laboratory, Itahari. The report was used as a primary data.

\section{Secondary Data}

Reports Journals, Project Reports, Similar studies, Books, Websites provides baseline information of secondary data. Audit reports of Itahari Water Supply Project and Duhabi Water Supply Project were taken as secondary data.

\section{Data Compilation and Analysis}

As mentioned above, this study was mainly based on descriptive and analytical techniques for analyzing different objectives of the study. Hence, after completion of collecting required data, the data were presented in tabular form in clear and logical manner. Information obtained from respondents were analyzed with the help of simple statistical tools and technique like percentage method. As far as possible the results obtained after analysis was represented in graphical form.

\subsection{Causes of Water Supply and Sanitation Project Performance Deficiency}

While interviewing WUSC members and consulting with expert, it was found that on the handover phase of the system, there was haste from user's side to use water from the new system. The DWSS also wants to transfer the management as soon as possible so that it can focus its resources on another project in another area. Within these hasty circumstances, even when the all the parties tend not to be prepared for it, the management transfer of the projects happens. So, the root causes of Water Supply and Sanitation project performance deficiency are due to:

- Limitations in the system's condition

- Limitations in the capacity of the WUSC

\section{Limitations in the System's Condition}

These are related to water supply system's condition i.e. acceptability of system's condition. There are three main causes related to water supply system's condition which are follows:

\section{i. Worsening Functionality}

With reference to obtained result on 4.1.1 (A) - I, ii, iii \& iv, it was found that the project, in which regular operation and maintenance, testing of pressure of the system, quickly response of WUSC staffs while problems occurs, transparency in the systems were maintained, the project functioned well otherwise the system became worsen functionality. The study indicated that Itahari WSSP was functioning well because they maintained pressure of flow, water demand of users, quick response of staffs whereas in Duhabi WSSP they did not maintain such features. The study also concluded that the system handover to the WUSC without checking its design value, the system became worsen. From the Expert Consultation and FGD with WUSC members, it was found that for new water supply system, the contractor just constructed the component and laid the distribution pipes as set in the engineering design. After completion, there were hasty in management transfer, so nobody was willing to check if the system was delivering the services as it should. For the effective management transfer, the system should be checked and if service 
parameters were not found as set by the engineering design then should be calibrated to deliver as for the design. The system should be calibrated for pressure, flow, velocity and valves openings. Similarly, the components like treatment plant also be checked whether it is delivering water as per expected parameters. Hence the first main cause of water supply system failure is "Handover the water supply system to WUSC without checking its design value i.e. without calibration."

\section{ii. Worsening Water Quality}

With reference to obtained result on 4.1.1 (B) - I, ii\& iii, the study revealed that worsening water quality weakens the confidence over the system and it is one of the important issues in functionality of the system. The majority of respondents views proved that the system of water supply functioning well only when the water quality of the system get improved. From the Expert Consultation and FGD with WUSC members, it was found that during the construction of project, the pipes are laid with simply cleaning dirt, dusts and debris inside the pipes. They are not sterilized. Similarly, components like tanks are also simply cleaned with normal water. So, when first put on line, new distribution systems and structural components should be sterilized to kill bacteria. Shock chlorination is one of the most popular methods for sterilizing pipelines and system components. Hence another main cause of water supply system failure is, "Worsening Water Quality i.e. handover the water supply system to WUSC without sterilization of water supply components".

\section{iii. Lost Information}

With reference to obtained result on 4.1.3 (C) - I \& ii, the study revealed that loss of information reduces functionality of the project. Itahari WSSP is functioning well in comparison with Duhabi WSSP because of their good information system. According to the expert consultation it was found that during the hasty situation of management transfer, the WUSC were not that much bothered of project documents. This information gradually fades out from the memory of WUSC members. But after several years when there were lots of changes in project features and there were new WUSC members this information was lost somewhere. Sometime the WUSC members who loosed his election did not want to share this information. For example, after sometime they would even be unable to find the exact route of pipe laying, location of valves. This was simply due to the ignorance and lack of understanding the gravity and usefulness of project information. For the few years WUSC members can remember the project information. The handover of a project to the client at the end of construction was a very important stage of the project procurement process. A well organized, efficient and effective transfer of information from project works to the client was essential. Hence another main cause of water supply system failure is "Lost of water supply project information i.e. handover the water supply system to WUSC without providing Project Completion Document ".

\section{Limitations in the capacity of the WUSC}

These are related to WUSC's capacity i.e. WUSC's capacity is ready to take over the system. There are three main causes related to WUSC's capacity's condition which are follows:

\section{i. Standard Process}

The study revealed that unsystematic office process cause failure of organization. Since Itahari WSSP followed systematic process, their organizations capacity raised up whereas in the absence of such standard process in Duhabi WSSP, organization capacity goes down. According the Expert 
Consultation, it was found that Most of WUSC in Nepal are not aware of any process and service delivery standard. This problem is mainly due to the absence of working directives and service standards. Since WUSC is service delivering organization, there should be service delivery standards for its own operation. These service delivery standards should be documented and be in knowledge of consumers for transparency purpose. These documents serve the purpose of management improvement. These quality documents are process documents to achieve the certain standard and uniformity in office management. Though the WUSC has inexperienced members and staffs they could be trained for WUSC's process and service standard. Hence another main cause of water supply system failure is "Handover the water supply system to WUSC without providing and training of "Water Operators Standard" document ".

\section{ii. Financial Sustainability}

The study revealed that regularly paying tariff, high rate of tariff, and implementation of business plan make the project sustainable. Since Itahari WSSP followed such type of financial features, their organizations raised up whereas in the absence of such financial features in Duhabi WSSP, organization goes down. According the Expert Consultation, it was found the WUSC members were elected from the community. During the election they generally promised not to increase water tariff. According to the government rules of the management transfer they do not provide any financial support from public expenditure. This poses serious threat to the financial health of the system. Being small community system WUSC do not have any other financial source than tariff. They also do not have skill of fund generation. This problem is mainly due to the lack of document which describes vision, objective, strategies and programs of the water supply system for financial sustainability. Hence another main cause of water supply system failure is "Handover the water supply system to WUSC without making the WUSC financial sustainable i.e. without developing Business Plan.

\section{iii. Open Defecation}

The study revealed that Dignity and Health is also one of the main issues in sustainability of project and it is seen that the service area declared ODF was more functional than the area not declared ODF. In terai region most of the area become water logged in rainy season, open defecation weakens the confidence over the system. The open defecation is due to the multiple causes such as cultural practice, being captive of their tradition and deterring changes is the main cause of open defecation. Hence another main cause of water supply system failure is "Open Defecation i.e. handover the system without making the service area Open Defecation Free.

\subsection{Short Comings of Management Transfer Process of the System}

The short comings of management transfer process of the system are follows:

\subsubsection{Worsening Functionality}

It was found that the water supply system should be calibrated for pressure, flow, velocity and valves openings. Similarly, the components like treatment plant also be checked whether it is delivering water as per expected parameters. Without calibration as per design, the system became worsen. So, for effective management transfer process of the system, the first indicator should be: 
Indicator 1: Calibration of the system

According to the Expert Consultation and FGD with WUSC's members, the following methodologies and responsibilities were found.

\section{Methods:}

1) Calibration of components (eg. treatment unit) for its output parameters

2) Calibration of Water Distribution Network for its residual pressure, discharge, velocity, pipes diameter and series

3) Calibration of valves for its opening

4) Recording of GPS location of each nodes, valves and structural components

Responsibility: Contractor in close coordination with design and supervision consultant

\subsubsection{Worsening Water Quality}

It was found that worsening water quality weakens the confidence over the system and it is one of the important issues in functionality of the system. So, for effective management transfer process of the system, the second indicator should be:

Indicator2: Sterilization of the system

According to the Expert Consultation and FGD with WUSC's members, the following methodologies and responsibilities were found.

\section{Methods:}

Inspection and Repair of distribution systems and components.

1) Chemical Sterilization and Rinsing: - Calculate total water volume in structures and distribution systems, Determine Time Frame or "Method Exposure", Add the Correct Amount of Bleach, Wait for Disinfection to Occur, Flush water volume

2) Post-Sterilization Maintenance

3) Encourage for shock chlorination even to the plumbing in residential and commercial buildings

Responsibility: The responsibility of sterilizing the system rests on the contractor

\subsubsection{Lost Information}

The study revealed that loss of information reduces functionality of the project. So, for effective management transfer process of the system, the third indicator should be:

Indicator 3: Project completion document is handed over to WUSC

According to the Expert Consultation and FGD with WUSC's members, the following methodologies and responsibilities were found. 
Methods:

1) Prepare the documents which contains:

- Licenses, Certificates and Registrations

- Warranties, Insurances, Reporting and claims

- Defects Liability Period - Maintenance

- Project costs

2) Prepare 'As built' Information and drawings

Responsibility: The responsibility of preparing and handing over of the project completion documents rests on DWSS. The contractor may ask assistance from contractor

\subsubsection{Standard Process}

The study revealed that unsystematic office process cause failure of organization. So for effective management transfer process of the system, the fourth indicator should be:

Indicator 4: WUSC's "Water Operators Standard" document is in place and WUSC's members and office are trained for it.

According to the Expert Consultation and FGD with WUSC's members, the following methodologies and responsibilities were found.

\section{Methods:}

1) WOSs documents are developed by WUSC in close consultation with the experts from DWSS.

2) National Water Supply and Sanitation Training Centre (NWSSTC) provides orientation training to the WUSC's members and its office staff, but for particular operating process documents (e.g. SOP of Treatment plant) the concerned supplier provides training at the site itself.

3) This Quality document is owned and followed by the WUSC.

Responsibility: The preparation of WOS documents rests on WUSC. It may ask DWSS for technical assistance. For training on WOS, the responsibility rests on DWSS.

\subsubsection{Financial Sustainability}

The study revealed that regularly paying tariff, high rate of tariff, and implementation of business plan make the project sustainable. Absence of these feature the system became worsen. So for effective management transfer process of the system, the fifth indicator should be:

Indicator 5: WUSC's Business Plan is in place.

According to the Expert Consultation and FGD with WUSC's members, the following methodologies and responsibilities were found. 


\section{Methods:}

1) National Water Supply and Sanitation Training Centre (NWSSTC) provides orientation training to the WUSC's members and its secretariat to develop Business Plan.

2) Business Plan is developed by WUSC in close consultation with the experts from DWSS.

3) This Business Plan is owned by the WUSC.

Responsibility: The responsibility of preparing Business plan rests on WUSC. It may ask DWSS for technical assistance.

\subsubsection{Open Defecation}

The study revealed that Dignity and Health is also one of the main issues in sustainability of project and it is seen that the service area declared ODF was more functional than the area not declared ODF. So, for effective management transfer process of the system, the sixth indicator should be:

Indicator 5: Access to and use of sanitary toilet by all in project area.

According to the Expert Consultation and FGD with WUSC's members, the following methodologies and responsibilities were found.

\section{Methods:}

1) Finding the barriers and bottle necks

2) Focused campaign

3) Improving financial access

4) Constructing the toilet

Responsibility: The responsibility of constructing toilets in project area rests on WUSC. The WUSC may ask DWSS for technical and financial assistance.

\section{Conclusions}

Summary of the Indicators

\begin{tabular}{|l|l|l|l|l|}
\hline S.N. & Indicators & Thematic area & $\begin{array}{l}\text { Expected } \\
\text { Improvement }\end{array}$ & Methods \\
\hline 1 & System is Calibrated & $\begin{array}{l}\text { Technical } \\
\text { (Water Supply) }\end{array}$ & $\begin{array}{l}\text { Improved } \\
\text { functionality of the } \\
\text { system, Reduces } \\
\text { NRW }\end{array}$ & $\begin{array}{l}\text { Iteration unless } \\
\text { system is calibrated } \\
\text { and stable by } \\
\text { contractor }\end{array}$ \\
\hline 2 & System is sterilized & $\begin{array}{l}\text { Technical } \\
\text { (Sanitation) }\end{array}$ & $\begin{array}{l}\text { Improved sanitary } \\
\text { condition of the } \\
\text { system }\end{array}$ & $\begin{array}{l}\text { Flash chlorination by } \\
\text { contractor }\end{array}$ \\
\hline 3 & $\begin{array}{l}\text { "Water Operators } \\
\text { Standard (WOS)" } \\
\text { document is in } \\
\text { place. }\end{array}$ & $\begin{array}{l}\text { Operational } \\
\text { Management }\end{array}$ & $\begin{array}{l}\text { Improved office } \\
\text { management }\end{array}$ & $\begin{array}{l}\text { 1. DWSS trains } \\
\text { WUSC to prepare } \\
\text { WOS documents } \\
\text { 2. Supplier prepares } \\
\text { and trains for SOPs }\end{array}$ \\
\hline
\end{tabular}


DOI: 10.5281/zenodo.2550077

\begin{tabular}{|l|l|l|l|l|}
\hline 4 & $\begin{array}{l}\text { WUSC's Business } \\
\text { Plan is in place. }\end{array}$ & Financial & $\begin{array}{l}\text { Better financial } \\
\text { functioning and } \\
\text { service expansion }\end{array}$ & $\begin{array}{l}\text { DWSS trains WUSC } \\
\text { to prepare Business } \\
\text { Plan }\end{array}$ \\
\hline 5 & $\begin{array}{l}\text { Access to and use of } \\
\text { sanitary toilet by all } \\
\text { in project area. }\end{array}$ & $\begin{array}{l}\text { Health } \\
\text { status and dignity } \\
\text { document is handed } \\
\text { over }\end{array}$ & $\begin{array}{l}\text { Triggering by WUSC } \\
\text { and DWSS }\end{array}$ \\
\hline 6 & $\begin{array}{l}\text { Project completion } \\
\text { Information }\end{array}$ & $\begin{array}{l}\text { Project documents are } \\
\text { up to date }\end{array}$ & $\begin{array}{l}\text { Contractor prepares } \\
\text { documents }\end{array}$ \\
\hline
\end{tabular}

Due to this technical short coming, the system was lacking community acceptance in Duhabi whereas in Itahari community acceptance level was high. The systems were not accepting standard process and even lacking its financial sustainability and open defecation was more in case of Duhabi whereas these problems were less in Itahari WSSP. In this way the main causes of water supply system failure were worsening functionality, worsening water quality, information lost, lacking in standard process as well as financial sustainability and open defecation in service area.

\section{References}

[1] Abrams. (2013). Understanding sustainability of local water service. Africa: www.africanwater.org.

[2] ADA. (2011). Manual Capacity Development. Vienna, Austrian Development Agency. Retrieved September 24, 2014, from [Online]. Available at: http://www.entwicklung.at/uploads/media/Manual_Capacity_Development.pdf.

[3] Bitew, M. M. (2013). EVALUATION OF THE LEVEL OF SERVICE RENDERED BY FUNCTIONING. Ethiopia: Addis Ababa University.

[4] Citi. (Website). Financial Capability and Asset Building, . Retrieved August 18, 2014, from [Online]. Available at: http://www.citifoundation.com/citi/foundation/pdf/Citi_Foundation_FinCap.pdf.

[5] Danilenko, B. C. (2014). The IBNET Water Supply and Sanitation Blue Book 2014. Retrieved from [Online]. Available at: https://openknowledge.worldbank.org/bitstream/handle/10986/19811/9781464802768.pdf.

[6] Das, J. (2011). Monitoring and Evaluation System in Water Supply Project in Saptari District. Kathmandu.

[7] Dhital, C., 2014. Operation and Maintenance Management of Mangadh WSSP. Kathmandu. Master Thesis. Changunarayan, Bhaktapur, Nepal: Nepal Engineering College.

[8] DWSS. (2003). DESIGN GUIDELINES FOR COMMUNITY BASED GRAVITY FLOW RURAL WATER SUPPLY SCHEMES. Kathmandu: DWSS.

[9] DWSS. (2013). Welcome Page. Retrieved January 155, 2013, from http://dwss.gov.np/content/1/Welcome

[10] DWSS/NMIP. (2014). Nationwide coverage and functionality Status of Water Supply and Sanitation in Nepal. Kathmandu: NMIP.

[11] GLEASON, K. (2013). Standard Operating Procedures (SOPs) - a quick guide. Vancouver: clinfield.

[12] GON. (2004). National Policy on Rural Drinking Water Supply and Sanitation. Kathmandu: GON.

[13] GTZ. (2003). Policy Paper No.1, Capacity Development or Sustainable Development. Retrieved August 16, 2014, from [Online]. Available at: http://www.camlefa.org/documents/GTZ_CD_for_sustainable_development.pdf. 
[14] GTZ. (2012). Capacity Development in the Water Sector: German experiences and services. Berlin, Germany: German Water Partnership.

[15] Hawks, D. D. (2008). SOP.

[16] JICA. (2013). JICA Project Brief Note (Nepal), Project for Capacity Development on Water Supply in Semi-Urban Areas. Nepal. Kathmandu: Japan International Cooperation Agency (JICA).

[17] Joshi, S. (2011). Community participation and Ownership of Sanitation and Hygiene in Western Nepal. USA: Diaconia University.

[18] Kelchner, L. (Webpage). The Importance of Organizational Capability. Retrieved August 22, 2014, from [Online]. Available at: http://smallbusiness.chron.com/importance-organizational-capability13295.html.

[19] Laine, M. (2012). BEST PRACTICES FOR PROJECT HANDOVER IN MIDDLE-SIZE ORG. OSLO: HAAGA-HELIA.

[20] Mebrahtu. (2012). Assessment of CMP approach in developing rural water supply. Benishangul Gumuz, Ethiopia: Addis Ababa University.

[21] Mishra AK,Acharya SR. Performance Assessment of Salyankot Water Supply Project in PostEarthquake Scenario of Nepal. J Adv Res GeoSci Rem Sens 2018; 5(3\&4): 23-40

[22] Mishra AK.Sustainability and Risk Assessment of Salyankot Water Supply Project in PostEarthquake Scenario. International Journal of Operations Management and Information Technology. (2018); 8 (1) pp. 1-30 available at http://www.ripublication.com

[23] Mishra AK, Rai S. Comparative performance assessment of eco-friendly buildings and conventional buildings of Kathmandu valley", International Journal of Current Research 2017; 9(12): 62958-62973.

[24] Mishra AK, Bhandari S. Performance Assessment of Ongoing Construction Projects under Town Development Fund, Nepal, Int j Adv Res Civil Stru Engr 2018; 1(1\&2): 27-39.

[25] Mishra AK, Shrestha M. Health and Safety Status of Casual Workers in Road Improvement Project Kathmandu Valley, Nepal, International Journal of Engineering Technology Science and Research (IJETSR) 2017; 4(9): 1187-1199. www.ijetsr.com ISSN 2394-338

[26] Mishra AK. Assessment of Human Resource Capacity of Construction Companies in Nepal. J Adv Res Jour Mass Comm 2018; 5(4): 14-25.

[27] Mishra AK. Implementation Status of Value Management in Project Management Practice in Nepal. International Journal of Management Studies. DOI URL: http://dx.doi.org/10.18843/ijms/v6i1(1)/13

[28] MoPPW. (2004). Rural Water Supply and Sanitation National Policy, 2004 . Kathmandu: Ministry of Physical Planning and Works (MOPPW).

[29] NEWAH. (Website). Cross Cutting Themes. Retrieved from [Online]. Available at: http://newah.org.np/index1.php?option=information\&id=28

[30] NMIP. (2014). National coverage and functionality status of water supply and sanitation in nepal. Kathmandu: DWSS.

[31] Nyumbu. (1990). Water supply and sanitation: handbook of financial principles. Geneva, Switzerland: World Health Organization, Community Water Supply.

[32] OECD. (2006). The challenge of capacity development - Working towards good practice, Paris: Organization for Economic Cooperation and. Retrieved September 24, 2014, from [Online]. (OECD). Available at: http://www.oecd.org/development/governance-development/36326495.pdf.

[33] Razak, H. (2014). Annual Drinking Water Quality Report. CITY OF SAN DIEGO: Dan Reynolds. RWSS. (Website). Project Information. Retrieved from [Online]. Available at: http://www.rwss.org/contents.php?mainid=13

[34] SEIU. (2014). WSSS policy. Kathmandu: SEIU.

[35] UNDP. (2004). A Review of Public Participation in the Rural Water and Sanitation Setting. Canada: UNDP.

[36] UNDP. (2008). Capacity Development: Practice Note. [Online]. Available at: 
http://www.undp.org/content/undp/en/home/ourwork/capacitybuilding/overview.html.

[37] UNICEF. (2012). Eliminate Open Defecation. India: UNICEF India.

[38] USEPA. (1999). Handbook for Capacity Development: Developing Water System Capacity Under the Safe Drinking Water Act as Amended in 1996. Retrieved August 16, 2014, from [Online]. Available at: http://www.epa.gov/ogwdw/smallsystems/pdfs/regcoor.pdf

[39] USEPA. (2001). Building Water System Capacity: A Guide for Tribal Administrators. Retrieved August 16, 2014, from [Online]. Available at: http://www.epa.gov/ogwdw/smallsystems/pdfs/tribalbuildcap.pdf.

[40] USEPA. (2008). National Capacity Development Strategic Plan,. Retrieved August 16, 2014, from [Online]. Available at: http://www.epa.gov/safewater/smallsystems/pdfs/report_smallsystems_capacitydevelopment_stra tegicplan.pdf

[41] WB. (2009a). he Capacity Development Results Framework: A strategic and results oriented approach to learning for capacity development. Retrieved from [Online]. Available at: http://siteresources.worldbank.org/CSO/Resources/228716-1369241545034.pdf.

[42] WB. (2009b). Water Operators Partnership - Africa Utility Performance Assessment. Retrieved from [Online]. Available at: http://www.wsp.org/sites/wsp.org/files/publications/WOP_Report.pdf.

[43] WB. (2010). Sustainable Management of Small Water Supply Systems in Africa, Practitioners' Workshop Report. Retrieved August 15, 2015, from [Online]. Available at: http://www.wsp.org/sites/wsp.org/files/publications/Sustainable_Management_of_small_water_s upply_systems_in_Africa_English.pdf.

[44] WB. (2012). Guide to Evaluating Capacity Development Results. Retrieved from [Online]. Available at:

https://wbi.worldbank.org/wbi/Data/wbi/wbicms/files/drupalacquia/wbi/Guide\%20to\%20Evaluati ng\%20Capacity\%20Development\%20Results_0.

[45] Webpage. (2008). Advantage and Chalanges of community participation in community economic development. morogoro: webpage.

[46] WELL. (1998). DFID guidance manual on water supply and sanitation programmes. Loughborough University, UK: WELL, WEDC.

*Corresponding author.

E-mail address: anjaymishra2000@gmail.com/er.arunkarna@gmail.com 